\title{
"Ja tutaj piszę o sobie". Uwikłania pamięciolożki
}

Maria Kobielska

TEKSTY DRUGIE 2017, NR 1, S. 393-404

DOI: $10.18318 /$ td.2017.1.31

$\mathbf{T}$ ytułowy cytat pochodzi z pierwszej części Festung Warschau Elżbiety Janickiej, z fragmentu, w którym autorka kreśli swój stosunek do kultury pamięci, jakiej kształt wyłania się z jej naładowanej emocjami analizy. Jego kontekst stanowi rozdziałek zatytułowany Plac Krasińskich. Janicka analizuje w nim Pomnik Powstania Warszawskiego, składający się, jak wiadomo, z grup spiżowych postaci - powstańców i ludności cywilnej Warszawy, tuż przed upadkiem Starówki, którą zaraz opuszczą kanałami. W przypisie umieszcza uwage "pomnikowa kobieta z dzieckiem schodzi do kanału. Jest to sprzeniewierzenie się rzeczywistości historycznej, czyli kłamstwo"1. To kłamstwo pomnika polega na tym, że ewakuacja kanałami obejmowała wyłącznie powstańców, cywile zostali - o czym pisze dalej cytowany przez Janicką Tomasz Eubieński - pozostawieni na terenie zajmowanej przez Niemców Starówki. Dramatyczna ewakuacja okazuje się jednak miejscem pamięci tak silnym, że włącza, wkleja
Maria Kobielska - dr, pracuje w Katedrze Antropologii Literatury i Badań Kulturowych na Wydziale Polonistyki UJ, gdzie współtworzy też Ośrodek Badań nad Kulturami Pamięci. Zajmuje się najnowszą literaturą i kulturą polską w kontekście pamięci, przeszłości i polityki. Ostatnio opublikowała książkę Polska kultura pamięci wXXI wieku: dominanty.Zbrodnia katyńska, powstanie warszawskie i stan wojenny (2016). Kontakt: maria.kobielska@ gmail.com

1 E. Janicka Festung Warschau, Wydawnictwo Krytyki Politycznej, Warszawa 2011, s. 85. 
w siebie dalsze sensy, klisze z repertuaru polskiej kultury pamięci. Janicka cytuje Martę Zielińską, która pisze - oczywiście w dobrej wierze - o „wynalezieniu kanałów" przez Polaków jako drogi transportu w czasie powstania warszawskiego. To kolejne „sprzeniewierzenie się rzeczywistości historycznej”: tak samo używane były ponad rok wcześniej, w czasie powstania w getcie. Skąd ta łatwość, z jaką skleja się pamięciowy amalgamat? Janicka odpowiada na to interesującym mnie najbardziej fragmentem:

Przechodzimy w tym zakresie [a więc pamiętania i łączenia pamięci w spójną całość - dop. M.K.] intensywny trening. My, którzy wygraliśmy pod Grunwaldem i pod Somosierrą, i zwycięsko zremisowaliśmy na Wembley. Trening warunkujący. Żeby można było patrzeć i nie widzieć. Żeby można było słuchać i nie słyszeć. Żeby można było wiedzieć i nie przyjmować do wiadomości. I życie przeżyć w taki sposób. Nie krytykuję autorki [Zielińskiej]. Ja tutaj piszę o sobie. ${ }^{2}$

W tym ultrazaangażowanym tekście, jednym z najostrzejszych mi znanych na gruncie polskiego pamięcioznawstwa, kluczowe są dla mnie następujące momenty: po pierwsze, oczywisty protest przeciwko wymienionym aspektom polskiej kultury pamięci, jej wprost wyrażona epistemologiczno- etyczna ocena. Po drugie, wyeksponowanie retorycznego ukształtowania tekstu. Po trzecie, pojmowanie wspólnotowego „my”: przynależność do tej formacji polega tu na podzielanych z jej innymi członkami, domyślnych założeniach, pozwalających na wybiórcze - kierowane przez wspólnotowe wzorce - postrzeganie świata przy jednoczesnej redukcji poznawczego dysonansu. Po czwarte wreszcie, ostatnie zdanie, które, jeśli wziąć je za dobrą monetę, przetwarza naszkicowany obraz: określa, posługując się językiem Donny Haraway, usytuowanie zaangażowanej badaczki wobec badawczej relacji z badaną pamięcią i jej urządzeniami. Parafrazując, Janicka „tutaj pisze” o tej kłamliwej pamięci i zarazem „pisze o sobie”, jest z nią tożsama, i z tej tożsamości wynika ta ocena, ten styl i to zaangażowanie. To spostrzeżenie będzie dla mnie istotne, gdy dalej postaram się sformułować moje rekonesansowe uwagi na temat przyczyn, legitymizacji i konsekwencji zaangażowania w sytuacji podejmowania kulturoznawczych badań nad pamięcią.

2 Tamże, s. 86-87. 
Długie dyskusje o zaangażowaniu humanistyki - jego przyczynach, konsekwencjach, postaciach, wersjach, zasadności, konieczności, szkodliwości - przynoszą wrażenie, że większość, jeśli nie wszystkie pytania dotyczące tej materii zostały już dobrze i dobitnie sformułowane. Na polskim gruncie szczególnie dogłębnie w odniesieniu do własnej dyscypliny analizowali ten problem antropolodzy kulturowi - na łamach warszawskiego pisma "(op.cit.)", ale także w kolejnych publikacjach książkowych. Antropolodzy i antropolożki przeważali też np. wśród autorów tomu o podsumowującym tytule Zaangażowanie czy izolacja? Wspótczesne strategie społecznej egzystencji humanistów, wydanego w serii Colloquia Humaniorum przed prawie dziesięciu laty. Polityczność humanistyki jest też jednym z głównych tematów ostatniej akademickiej książki Michała Pawła Markowskiego, który już na jej pierwszych stronach deklaruje, że „humanistyka ma znaczenie polityczne. Nie w wąskim znaczeniu, ale możliwie jak najszerszym”, ponieważ „efekty jej studiowania mają znaczenie dla wspólnoty, w której te studia się odbywają" - i wielokrotnie potem wraca do tej diagnozy, przeformułowując ją na różne sposoby.

Pytania zostały więc zadane i - jak by się wydawało - padły propozycje dobitnych odpowiedzi, w wielu wypadkach bardzo przekonujące. Jeśli jednak mogę sobie pozwolić na to, aby - jak w tytułowym cytacie - napisać tu nieco o sobie, lektura tych odpowiedzi pociąga za sobą pewien niedosyt, gdy chciałabym potraktować je jako wskazówki przy rozwiązywaniu dylematów, z którymi faktycznie się spotykam w swojej praktyce badawczej. Wydaje się, że rzadko stanowią ekspresję bądź przepracowanie problemów z zaangażowaniem, problemów, jakie wiążą się z zadawaniem sobie pytania: czy wolno mi - jako badaczce - angażować się w to w ten właśnie sposób? Czy i dla kogo wynikną z tego jakieś korzyści? Czy mogę oceniać, sugerować, ironizować? Komu służę? Aby choć zasygnalizować konkretny przykład: na jaki stopień oceny - i afektu - mogę (a może powinnam?) sobie pozwolić, gdy analizuję ostatni boom polskiej kultury pamięci, jaki stanowi intensyfikacja upamiętnień tzw. żołnierzy wyklętych?

Wydaje mi się, że we wspomnianych odpowiedziach zarysowują się dwie główne, niekiedy komplementarne taktyki. Jedna z nich opiera się na totalnym rozumieniu zaangażowania, które staje się wtedy właściwie synonimem

3 M.P. Markowski Polityka wrażliwości. Wprowadzenie do humanistyki, Universitas, Kraków 2013, S. 31. 
uprawiania humanistyki. Kilka przykładów ze wspomnianego tomu: Adam F. Kola pisze w formule niemal zaklęcia: „[humanistyka] była, jest i zawsze będzie zaangażowana: społecznie, politycznie i etycznie. Czy jej się to podoba, czy też nie. Taka jest jej rola"4. Paulina Abriszewska wpisuje zaangażowanie w samą definicję literaturoznawstwa, wyprowadzając ten wniosek z podejmowanego w tej dyscyplinie „wielopoziomowego dialogu z badanym przedmiotem”, czyli literaturą, ze względu na jej „kulturowy charakter” i ,uwikłanie [...] we wszystkie dziedziny życia społecznego"s. Markowski podejmuje kolejną próbę doprecyzowania politycznego celu humanistyki:

głównym zadaniem humanistyki nie jest budowanie wiedzy na temat przeszłości, lecz przekształcanie społecznego imaginarium, a więc wpływ na to, jak i co ludzie myślą o świecie [...]. Zadanie to zwykle przypisuje się polityce, staram się więc powiedzieć, że zadanie, które stawia sobie humanistyka, jest polityczne na wskroś. ${ }^{6}$

Druga taktyka polega na oddzielaniu od siebie „dobrych" i „złych”, niedopuszczalnych, postaci zaangażowania. Marcin Brocki pisze, że przechodzi ono na tę stronę, gdy przyjmuje formę „politycznie, ideologicznie zaangażowanej aktywności społecznej”, i przeistacza się w „aktywizm, który oznacza utratę krytycznego dystansu, a więc dystansu będącego fundamentem poznania antropologicznego, dystansu, który umożliwia rozumienie"7. Markowski natomiast prędko dodaje do swej diagnozy „na wskroś politycznej” humanistyki następujące zastrzeżenie:

Humanistyka jednak nie zmierza do przekonania ludzi do tej lub innej racji, do tego lub innego zbioru wyobrażeń. Humanistyka nie skłania się ku którejś konkretnej treści społecznego imaginarium. [...] Humanistyka pokazuje, że nie istnieje jeden słownik, którym możemy świat objaśniać

4 A.F. Kola Zwierzę polityczne, czyli słów kilka o bałkanistach, a także o nieuniknionym zaangażowaniu humanistyki, w: Zaangażowanie czy izolacja? Współczesne strategie społecznej egzystencji humanistów, red. J. Kowalewski, W. Piasek, Instytut Filozofii Uniwersytetu WM w Olsztynie, Olsztyn 2007, s. 211.

5 P. Abriszewska O niewłaściwie zadanym pytaniu, czyli o zaangażowaniu i izolacji literaturoznawstwa, w: Zaangażowanie czy izolacja?..., s. 184.

6 M.P. Markowski Polityka wrażliwości..., s. 79-80.

7 M. Brocki Antropologia zainfekowana aktywizmem, w: Zaangażowanie czy izolacja?..., s. 177. 
[...]. Humanistyka uwrażliwia nas na to, że żaden z obiegowych słowników nie jest ostateczny i zawsze można go zmienić na inny. ${ }^{8}$

W efekcie zaangażowanie przeistacza się w projekt mnożenia i testowania interpretacji, który ma znaczenie przede wszystkim jako „projekt egzysten-

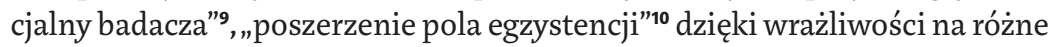
sposoby mówienia o świecie.

W wyniku sprzęgnięcia tych dwóch taktyk ostatecznie „dobrym” zaangażowaniem okazuje się takie, które wiąże się z konieczności z uprawianiem - w jakikolwiek sposób - humanistyki. Ta diagnoza humanistyki „koniecznie zaangażowanej" wydaje mi się przekonująca już na poziomie oczywistości: w końcu wiemy dobrze, że samo dokonanie opisu, analizy i interpretacji znaczącego świata wprowadza weń pewną zmianę. By użyć słów Koli, „scjentystyczno-pozytywistyczna wiara w Prawdę i Obiektywność Nauki"11 to erystyczny chochoł, postawa wyimaginowana przez jej przeciwników. Jednocześnie tak rozumiane „konieczne zaangażowanie” humanistyki jest oczywiście zupełnie nieproblematyczne. Nikt nie będzie się zastanawiać, czy etycznie jest się w ten sposób angażować i czy badaczka ma do tego prawo, gdy przez zaangażowanie rozumiemy samo - ostatni cytat z Markowskiego „zajmowanie się, przejmowanie się językami, dyskursami, którymi mówi się w sferze publicznej” oraz "poszerzanie pola egzystencji [przez] poszerzanie repertuaru dyskursów"12.

Co więcej - czy koncepcja „koniecznie zaangażowanej” humanistyki powoduje, że każdy tekst, każdy badacz i każda badaczka, wpadając w kategorię „zaangażowanych", są zaangażowani w ten sam sposób i w tym samym stopniu? Narzuca się, choćby tylko na podstawie własnych doświadczeń dotyczących różnych tematów i tekstów (choć wszystkie można usytuować w trajektoriach pewnych ideologii), odpowiedź przecząca. Założenie, że humanistyka jest „koniecznie zaangażowana”, pozwala co najwyżej przeformułować wspomniane dylematy: nie pytam już, ,czy się angażować”, ale w jaki sposób to robić, czy postawić i gdzie jakąś granicę - materia nierozwiązanych

8 M.P. Markowski Polityka wrażliwości..., s. 80.

9 Tamże, s. 39.

10 Tamże, s. 430.

11 A.F. Kola Zwierzę polityczne..., S. 214.

12 M.P. Markowski Polityka wrażliwości..., s. 430. 
problemów pozostaje jednak ta sama. Tak więc mimo pouczających spostrzeżeń i wniosków, jakie można wyciągnąć z tych odpowiedzi, ostatecznie, jak sądzę, oddalają one faktyczne pytanie o to, jak badać, skupiając się na generalnej charakterystyce badań, które i tak podejmujemy.

\section{***}

Ewa Domańska proponuje w kilku miejscach kategorię „intelektualnej szczerości” jako podstawową dla pracy badacza-humanisty, „użyteczne kryterium krytyki”"13 , ,stymulujące refleksje na temat niewłaściwego [i właściwego dop. M.K.] prowadzenia badań" ${ }^{14}$. Zdając sobie sprawę z obciążenia ryzykiem pewnej - jak też ostrzega badaczka - naiwności i banalności, kolejny raz napiszę tu o sobie: te oddalone pytania o zaangażowanie zadaję sobie naprawdę, nie na potrzeby generalnego wywodu, ale w kontekście konkretnych i szczegółowych dylematów. Jedną z kwestii, które w tym kontekście rozważam, jest hipotetyczny związek tego naprawdę z subdyscypliną, którą się zajmuję. Być może memory studies mają w sobie coś takiego, że nieproblematyczne „konieczne zaangażowanie” okazuje się na tym polu niewystarczające.

We wspomnianym artykule Adam Kola wychodzi od analizy tekstów pochodzących z pewnego obszaru humanistyki, który uznaje za specyficzne ekstremum zaangażowania. Jest to bałkanistyka, gdyż w jego ujęciu „nie można zajmować się Bałkanami w sposób niezaangażowany. Zawsze sympatyzuje się z jedną ze stron konfliktu"15. Specyfika bałkanistyki wypływałaby więc z uwarunkowań regionalnych, szczególnej postaci konfliktu, jaki umocowany jest poza metapoziomem badań - w rzeczywistości, którą bierze się za ich przedmiot.

Zastanawiam się, czy pamięciologia nie okazuje się również - choć nie na skutek takiego oczywistego mechanizmu - wyjątkowo drażliwym, politycznym obszarem, na którym działanie wyzyskuje sympatie i antypatie badaczki. Czy możliwa będzie pamięciologia apolityczna, czy można się nią zajmować bez „sympatyzowania z jedną ze stron konfliktu"?

E. Domańska Historie niekonwencjonalne. Refleksja o przeszłości w nowej humanistyce, Wydawnictwo Poznańskie, Poznań 2006, s. 66. wanej, PWN, Warszawa 2012, s. 177. 
Niekiedy wyrażano nadzieję, że w opozycji pamięci i historii ta pierwsza może stać się remedium na polityczność drugiej, neutralizować politykę historyczną, np. „stając się źródłem prawdy dla grup pozbawionych [w jej ramach - dop. M.K.] głosu"16. Jak sądzę, opis taki jaskrawo nie przystaje ani do sposobów działania kultur pamięci, ani do ich analiz tworzonych przez pamięciologów - już z tego prostego powodu, że owa reakcja na polityczność okazuje się równie zaangażowana i polityczna, a granica między polityką historyczną a polityką pamięci - raczej umowna. Te tematy nie tak często były poruszane przez pamięcioznawców. Przejrzenie roczników kwartalnika „Memory Studies”, podobnie zresztą jak „History and Memory”, pokazuje, że względnie rzadko pojawiają się w nich teksty teoretyczno-metodologiczne. Teoria memory studies to częściej pracownia narzędzi i terminów, za pomocą których konceptualizowane są pamięciowe praktyki, niż refleksja nad pozycją subdyscypliny wobec humanistyki, kultury i ludzkiego życia.

Niemniej jednak pojawiają się i tu uwagi o „koniecznym zaangażowaniu” pamięciologii. Już w pierwszym numerze „Memory Studies” z 2008 roku Karen E. Till postulowała, aby badacze uczyli się od pamięciowych artystów i aktywistów, jak rozumieć swoją pracę jako „społecznie odpowiedzialną praktykę"17. W jednym z ostatnich z kolei Wulf Kansteiner, autor redakcyjnego wstępu, zastanawia się nad ",akademickimi strategiami studiowania i krytyki pamięci społecznej" i uważa etyczną ocenę, mającą na celu oddziaływanie na rzeczywistość, za oczywisty czynnik tych strategii. „W końcu - pisze Kansteiner - pytania o to, co pamiętać, a co najlepiej zapomnieć, albo jak pamiętać odpowiedzialnie i w jakim celu, powinny nas wszystkich bardzo obchodzić"18.

Co interesujące, w ujęciu Kansteinera memory studies, tytułowa dziedzina zainteresowania pisma, okazują się jednak dystansować od tych pytań. Badacz kontrastuje z nimi inną subdyscyplinę - public history, posługując się w tym celu autodefinicjami autorów popularnych readerów, wprowadzających do obu obszarów. Historię publiczną (czy też, jak w nielicznych wystąpieniach na polskim gruncie - stosowaną) opisuje na tej podstawie jako „społeczną formę wiedzy ugruntowaną we współczesnym życiu, skupioną na

16 J. Kowalewski O problemach ze społecznym zaangażowaniem historiografii, w: Zaangażowanie czy izolacja?..., s. 115.

17 K. Till Artistic and activist memory-work: Approaching place-based practice, "Memory Studies" 2008 Vol. 1 (1), s. 99. Wszystkie przekłady cytatów z języka angielskiego są mojego autorstwa.

18 W. Kansteiner Ofmedia scandals and regimes of forgetting:Strauss-Kahn, Public History, and Memory Studies, "Memory Studies” 2015 Vol. 8 (4), s. 386. 
wyjaśnianiu, na jakie sposoby zwykli ludzie angażują się w przeszłość na poziomie osobistym, grupy czy rodziny"19; ; historia jest w tym ujęciu własnością tych, którzy są jej bohaterami. Subdyscyplina wygrywa chwiejną równowagę między „żywą obroną nieprofesjonalnych sposobów używania przeszłości i szacunkiem dla profesjonalnej historii [i jej metod - dop. M.K.]"20. Przytoczę dłuższy fragment, w którym Kansteiner sytuuje historię publiczną po stronie zaangażowania (a także kobiecości, afektywności, wspólnoty), studia nad pamięcią zaś - po stronie dystansu, akademickiego habitusu, kontroli nad dyskursem i - last but not least - męskości.

„Historia publiczna jest explicite ugruntowana etycznie i społecznie, służy sprawie historycznej sprawiedliwości. Memory studies mogą tolerować ten rodzaj politycznego zaangażowania, ale są przesiąknięte analitycznymi ambicjami, które wiążą się z ich poststrukturalistycznymi korzeniami. Z tych samych przyczyn pamięciologia wydaje się dużo mniej przyjazna używaniu historii (narrative appropriations) niż jej mniej ekspansywna siostra. Co więcej, kierują nią interdyscyplinarne i szczególnie teoretyczne ambicje - odwrotnie niż w wypadku historii publicznej. Badacze z dziedziny historii publicznej zapisują się w szeregi zwolenników danej sprawy. Ci, którzy pracują w dziedzinie memory studies, są wyposażeni w zestaw porządnych narzędzi teoretycznych, za pomocą których mogą eksplorować coraz szerszy interdyscyplinarny krajobraz" ${ }^{21}$.

Wydawałoby się więc, że zdaniem Kansteinera wspomniane w oczywisty sposób polityczne pytania - pytania o pożądany kształt kultury pamięci pozostają do pewnego stopnia poza zainteresowaniem „akademickiej” pamięciologii. Czy znaczyłoby to, że od momentu osiągnięcia pewnego poziomu zaangażowania badania z zakresu memory studies zbliżają się raczej do obszaru historii publicznej, tego aktywizmu dotyczącego przeszłości? Wskazanie tego momentu byłoby w oczywisty sposób problematyczne. W końcu z pewnością istotną część współczesnych memory studies wypełniają prace realizujące taki projekt humanistyki zaangażowanej, który można by określić za Ewą Domańską przy użyciu poręcznej formuły „humanistyki w obronie opresjonowanych"22. Taka pamięciologia wybiera na swój przedmiot zainteresowania

Tamże.

Tamże, s. 388.

E. Domańska Historia egzystencjalna..., s. 119. 
mniejszościowe, stabuizowane, niszowe bądź pozbawione (dotąd) możliwości pełnej artykulacji wersje pamięci. Można by ją nazwać, na wzór „krytyki towarzyszącej”, ,pamięciologią towarzyszącą", wspierającą analizowane teksty, umacniającą ich punkt widzenia. Najbardziej ewidentnym przypadkiem będzie, jak sądzę, szczególnie uwaga poświęcana studiom nad pamięcią odchodzącej generacji ocalałych z Holokaustu. Z kolei jednym z najlepszych, wydaje się, przykładów takiego badania towarzyszącego, które przyniosło spektakularne poznawcze i konceptualne efekty, są dla mnie teksty Marianne Hirsch dotyczące Mausa Arta Spiegelmana.

Zaangażowanie takiej pamięciologii oznaczałoby więc ujmowanie się za tym, co się bada, a także - ramię w ramię z „badanym" - wspólny sprzeciw wobec opresji głównego nurtu kultury. Jak jednak skonceptualizować odwrotną sytuację, w której to, co badane, spotyka krytyczny sprzeciw badaczki? Sytuacji takiej teoretycznie dałoby się uniknąć na poziomie wyboru tematu, uniemożliwiałoby to jednak dokonanie w jakimś stopniu całościowego opisu jakiejkolwiek kultury pamięci. Co więcej, jeśli wziąć pod uwagę zarysowany model „w obronie opresjonowanych", jego poważne potraktowanie prowadzi do „demaskowania działania władzy, opresji i wykluczania"23. Aby demaskować opresję głównego nurtu, większościowych wzorów pamięciowych, wyobrażonych protagonistów przeszłości i jej dominant, trzeba spojrzeć na mechanizmy ich działania, uczynić z nich - moim zdaniem, równoprawny - przedmiot badań. Konieczne pytanie dotyczy więc także sposobu odpowiedzialnego badania tekstów, którym nie sprzyjam, którym nie chcę - w wyłożonym wyżej sensie - towarzyszyć.

\section{***}

Zbliżając się do końca tego niewystarczająco konkluzywnego ciągu pytań, spróbuję usystematyzować poziomy, na których można mówić o zaangażowaniu, a więc tytułowym uwikłaniu badaczki pamięci.

Po pierwsze, jako kulturoznawczyni-badaczka pamięci muszę być zarazem jej użytkowniczką, funkcjonować wewnątrz środowiska, jakim jest kultura pamięci, kształtująca warunki mojego działania. Tematem analiz i interpretacji jest to, w jaki sposób działają kulturowe urządzenia do pamiętania - i skuteczność tego, jak pisze w cytowanym na początku fragmencie Janicka, „treningu". Oczywiście nie oznacza to absolutnego znawstwa czy afirmatywnego 
podejścia do każdego jego elementu. Uczestniczące rozpoznanie mechanizmów tej kultury wydaje mi się jednak niezbędne, aby móc je w następnym kroku - mimo ich oczywistości i domyślności - dostrzec i opisać. Ten rodzaj zaangażowania w badaną kulturę, który można też opisać jako zgodę na bycie pochwyconą w jej sieć, wydaje mi się stosunkowo nieproblematyczny, konieczny do zaakceptowania.

Taka badaczka-użytkowniczka kultury pamięci przechodzi z poziomu dostrzeżenia jej domyślnych zasad do analitycznego opisu ich działania, wraz z wiążącymi się z nimi stłumieniami i ograniczeniami. Staje się więc krytyczką pamięciowych praktyk - ta sytuacja może jednak rozwinąć się na różne sposoby, których bieguny sygnalizowałam wstępnie powyżej. Byłyby nimi nastawienie zupełnie negatywne i zupełnie afirmatywne wobec badanych tekstów i zjawisk. Badanie kultury pamięci, której jest się użytkowniczką, w sposób w pełni afirmatywny ma raczej niewielkie szanse na objęcie w całości jej niuansów i nieraz ukrytych założeń. Z kolei konsekwentne utrzymywanie postawy „krytykanckiej” w połączeniu z przynależnością - „pisaniem o sobie" - wydaje się wątpliwie osiągalne. Momenty rozpoznania i oceny często są nieoddzielne; szansę na osiągnięcie twórczego i intelektualnie szczerego poziomu zaangażowania widziałabym w odróżnieniu owego nastawienia oceny w punkcie wyjścia - od ostatecznej oceny w punkcie dojścia analizy.

Trzeci aspekt interesującej mnie postawy badawczej to pytanie o możliwość odpowiedzialnego przyjęcia roli pamięciowej aktywistki, ingerującej $\mathrm{w}$ równolegle badane kulturowe zjawiska. Taka osoba być może musiałaby wypracować odpowiedź na zadane przez Kansteinera pytanie o to, „co pamiętać, a co najlepiej zapomnieć", i swoją odpowiedź starać się popularyzować. Takie działanie wydaje się najbardziej niepokojące i w najbardziej jasny sposób wykraczające poza akademicką rolę. Wątpliwe pozostaje jednak nawet, czy nieakademiccy pamięciowi aktywiści powinni faktycznie decydować o tym, co ma być pamiętane. Sądzę, że lepszym doprecyzowaniem tego rozumienia zaangażowania mogłoby być użycie innych ról ze współczesnego aktywistycznego (a także edukacyjnego i nawet marketingowego) słownika: taka badaczka-użytkowniczka-krytyczka mogłaby w polu pamięciowych napięć próbować zająć raczej pozycję moderatorki czy w jakimś stopniu tzw. - pozwolę sobie użyć makaronizmu - facylitatorki ${ }^{24}$. Facylitator to osoba,

24 Zdaję sobie sprawę, że używanie tego określenia w kontekście badań nad pamięcią i przeszłością wiąże się z pewnym problematycznym skojarzeniem - mianowicie facilitator pojawia się niekiedy oprócz (lub zamiast) bystandera, aby uzupełnić katalog ról wiążących się, jak to re- 
która wspomaga pracę w grupie, możliwie neutralnie ułatwiając komunikację między jej członkami i budując podstawy do porozumienia. Polityczność takiego zaangażowania polegałaby więc na dzieleniu się zdobytym dzięki, jak pisał Kansteiner, „porządnym narzędziom teoretycznym” rozeznaniem w pamięciowej sieci, aby uzyskać przynajmniej wzajemne rozpoznanie antagonistów.

Na koniec wrócę do wspomnianego już pierwszego numeru „Memory Studies", w którym o polityczność upomina się Susannah Radstone. Jak pisze:

studia nad pamięcią trafiają w samo sedno głównych kwestii współczesnych debat i walk politycznych. Należą do nich polityczne skutki nieprzerwanej obecności przeszłości - i przeszłych zranień - w teraźniejszości, a także współczesne wyzwania, jakie stawia narodom i osobom wykorzenienie z pamięci spowodowane przez migracje, uchodźstwo i stan wygnania. ${ }^{25}$

Radstone dostrzega w „pamięciologii w obronie opresjonowanych” w jej wariancie skupiającym się na traumie i „kulturze rany" zwrot przeciwny: jej zdaniem wędrujące pojęcie traumy, gdy staje się naczelną kategorią badawczą, skłania do pojmowania tego, co wspólne, polityczne i publiczne jako osobistego, jednostkowego i wyjątkowego. A także petryfikuje role ofiary i prześladowcy, poprzez które pojmowane są pamięciowe praktyki. Tymczasem wspomnianych wyzwań nie da się zamknąć w tych kategoriach. Badaczka postuluje wobec tego - jako drogę dla badań nad pamięcią - podjęcie „próby

kapituluje Jan Tomasz Gross, z "nastawieniem ze strony nieżydowskich współobywateli, którego doświadczyli Żydzi w krajach Europy okupowanej i zależnej od Hitlera" (Sprawcy, ofiary i inni, „Zagłada Żydów. Studia i Materiały” 2014 nr 10 (wydanie elektroniczne) pg.4013). Gross powołuje się w tym miejscu na pracę Mary Fulbrook o Będzinie, gdzie termin facilitator pojawia się w kontekście "ułatwiania" (co odbywa się, jak pisze Gross, również przez "bycie «obok», «nie-zainteresowanym», «nie-zaangażowanym»") funkcjonowania nazistowskiego systemu rasistowskiego prześladowania, a w konsekwencji Zagłady (M. Fulbrook A Small Town Near Auschwitz: Ordinary Nazis and the Holocaust, Oxford University Press, Oxford 2013). Według mojego rozeznania nie wpływa to jednak na równoległe określanie jako facilitation działań o charakterze moderacyjno-edukacyjnym, również w odniesieniu do pamięci Zagłady (posługuje się nim np. Instytut Yad Vashem, określając adresatów swojego podręcznika dotyczącego przeprowadzania edukacyjnych projektów o antysemityzmie i Zagładzie jako "facylitatorów i nauczycieli", http://www.yadvashem.org/yv/en/education/educational_materials/educational_guidelines.asp\# 13.12.2016). 
rozumienia kultury - i kultury pamięci - jako dwuznacznej i zagadkowej, jako pola walki, jako szarej strefy"26. Na zakończenie chciałam zatrzymać się nad tą ostatnią metaforą.

Zasygnalizowana przez Elżbietę Janicką strefa domyślnych, niekwestionowanych i nieproblematyzowanych zasad to właśnie szara strefa kultury pamięci - obejmująca nie tyle ewidentne pamięciowe przedsięwzięcia, polityki i ich manifestacje, ile ich nieoczywiste, choć powszechnie milcząco podzielane powiązania i fundamenty. Ta szara strefa może zostać oświetlona właśnie przez zaangażowane badanie. Jednocześnie jednak ten obszar jest szarą strefą właśnie w tym sensie, że trudno na nim - na tym terenie pozbawionym sformułowanych przepisów - wyznaczyć tego zaangażowania bezpieczne granice. Ich lokalne usytuowanie pozostaje ryzykiem badaczki.

\section{Abstract}

\section{Maria Kobielska}

JAGIELLONIAN UNIVERSITY (CRACOW)

'Here I Write about Myeself': Exploring Memory Studies

What might motivate a researcher in cultural studies to explore memory in an engaged way, how can such engagement be legitimized, and what might be its consequences? Kobielska draws on broader debates on commitment in the humanities in order to describe the most frequent responses to questions about the permissibility of such engagement. She also points out why researchers' responses might be inadequate, especially when applied to particularly sensitive, problematic and political areas of interest in the humanities today. Examining the specificity of commitment in the field of memory studies, Kobielska classifies ways of understanding the engagement of a person who studies memory, taking into account the fact that this researcher will be both a user of the culture of memory she studies and at the same time a critic, an activist in the field of memory, a moderator and facilitator of social and cultural processes of remembering.

\section{Keywords}

memory studies, engagement, engaged humanities 